\title{
Effects of diets containing processed cassava peel meal on performance and feed
} economies of growing red Sokoto bucks

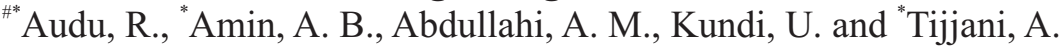

"Department of Animal Science, Federal University Dutse, Jigawa State, Nigeria.

"Correspondence author: auduramatu28@gmail.com; +2348063595401

\section{Abstract}

An experiment was carried out to evaluate the effects of differently processed cassava peel meal on the performance and economies of growing red sokoto bucks. Four experimental diets were formulated; diet $T_{1}$ (control) contained $20 \%$ sun-dried cassava peel meal while diets $T_{2}, T_{3}$ and $T_{4}$ contained $20 \%$ soaked, $20 \%$ boiled and $20 \%$ fermented cassava peel meal, respectively. Each diet was fed to a group of 3 bucks for 70 days in a completely randomized design. Among the differently processed cassava peel meals included in the diets of growing red sokoto bucks, inclusion offermented cassava peel meal significantly $(p<0.05)$ increased the final weight (19.63 kg), weight gain (6.63 kg) and total feed intake (19.93 kg) of the bucks; no significant effect was observed on other performance indices. There was also a significant $(p<0.05)$ reduction in the feed cost per kilogram weight gain of bucks fed diet containing fermented cassava peel meal. It was therefore concluded that inclusion of fermented cassava peel meal in the diets of growing red sokoto bucks resulted in better performance of the bucks and reduced the cost of feed per kilogram weight gain.

Keywords: Performance, Red Sokoto bucks, Cassava peel meal, Processing methods, Cost economies

\section{Introduction}

Products from food animals provide over 33 percent of protein consumed in human diets and about 16 percent of food energy globally (Martin, 2001). In Nigeria, the gap between supply and demand for animal products is widening as a result of increase in population, rapid urbanization, growing income, changing lifestyle, food preferences and several land conflicts (Anya and Ozung, 2018). Goats provide over 1.97 million tonnes of meat annually representing $3.5 \%$ of total world meat production and $8.5 \%$ of total estimated meat production in developing countries (Ozung et al., 2011). The productivity of goats under the prevailing traditional extensive production system is low mainly because of feed scarcity and lack of adoption of improved technologies and management practices (Kumar et al., 2010). Feed accounts for $60-70 \%$ of total cost of livestock production (Akpodiete and Inoni,
2000) and its inadequacy in quality and quantity could lead to undesirable situations such as low nutritional status, poor weight gain, poor reproductive ability, poor production, poor health condition and poor conversion ratio (Fajemisin et al., 2015). Fibrous crop residues are poor sources of fermentable nitrogen as their crude protein is below the level required by rumen microorganism. These crop residues are equally low in easily degraded carbohydrates, minerals and other nutrients required to balance the products of digestion to requirements, leading to limited intake, poor rumen function and low animal productivity (Anya and Ozung, 2018). The nutritional needs of goats can thus be addressed through the use of nonconventional feedstuff that are cheap and readily available (Ahamefule and Udo, 2010). One of such non-conventional feedstuff that is in abundance and can be a potential feed resource for livestock 


\section{Effects of diets containing processed cassava peel meal}

production is cassava peels. Cassava (Manihot spp.) is an important annual root crop renowned for its high supply of carbohydrates among staple crops. Cassava ranks fourth among food crops after maize, rice and wheat (FAO, 1991) and the peels are produced in large qualities from the processing of cassava for human, industrial and export purposes. Unfortunately, this enormous feed resource has received very little attention and is often discarded as waste (Ozung, 2009). Several processing techniques such as drying, toasting, cooking, extraction, autoclaving, fermenting, alkaline treatment and use of enzyme can be used to improve the nutritive value as well as remove or reduce antinutritional factors (Ayanwale, 1999; Ayanwale and Kolo, 2001). Cassava peels contain cyanogenic glycosides and phytate content and as such, should be processed prior to usage in ruminant feeding. Sundrying, ensiling and soaking plus drying of cassava peel will reduce its cyanogenic glycosides and phytate content and further preserve the nutritive quality (Oboh, 2006; Salami and Odunsi, 2003). Cassava peel is rich in metabolizable energy (3.03 Mcal $/ \mathrm{Kg}$ DM) (Anya and Ozung, 2018), thus serving as a good source of energy in ruminant feeding; either as a basal diet or as a supplement (Anaeto et al., 2013). Cassava peel has been documented as a valuable feed ingredient that significantly increased animal performance when added to ruminant diets; and is highly degradable in the rumen (81 percent dry matter degradability) (Oppong-Apane, 2013). Thus, this study is therefore aimed at evaluating the effect of various processing methods on the performance and cost economies of growing red Sokoto bucks.

\section{Materials and methods Experimental site}

The experiment was conducted at the Livestock Teaching and Research Farm,
Federal University Dutse, Jigawa State. Dutse lies on latitude $11^{\circ} 46^{\prime} \mathrm{N}$ and longitude $9^{0} 20^{\prime} \mathrm{E}$ (Abubakar et al., 2015) and has an elevation of $435 \mathrm{~m}$ above sea level (Oyebanji et al., 2017). The larger percentage of the local people engage mostly in farming and rearing of livestock such as cattle, guinea fowl, sheep, short and long-legged goat. The rainy season lasts from May to September with an average rainfall of between 600 to $1000 \mathrm{~mm}$ while high temperatures (mean annual temperature of $26.5^{\circ} \mathrm{C}$ ) are normally recorded between the months of April and September (Oyebanji et al., 2017; Abdurrahman and Kibon, 2017).

Collection and preparation of experimental materials

Cassava peels were collected from processing point at Kila village in Gwaram Local Government Area of Jigawa state. The cassava peels collected were divided into four portions. The first portion (control) consisted of dried cassava peels, the second portion was soaked for 24 hours prior to drying, the third portion was boiled for 35 minutes prior to drying, and the fourth portion was fermented for 4 days prior to drying. The dried, differently processed cassava peels were milled separately and stored in sacks for use in feed formulation.

\section{Experimental procedure}

Four (4) experimental diets were formulated with $20 \mathrm{~kg}$ each of the differently processed cassava peels. The treatments comprised of $\mathrm{T}_{1}$ (sun-dried cassava peels), $T_{2}$ (soaked cassava peels), $T_{3}$ (boiled cassava peels) and $\mathrm{T}_{4}$ (fermented cassava peels). The composition is shown in Table 1. Experimental animals were offered the concentrate diets in the morning at $4 \%$ of their body weights while groundnut haulm was offered in the evening. Experimental animals were provided fresh drinking water ad libitum. 
Record of daily feed intake was obtained for each animal while leftovers were collected and weighed every morning to obtain an estimate of intake.

Table 1: Gross composition (\%) of experimental diets

\begin{tabular}{lcccc}
\hline & \multicolumn{4}{c}{ Treatments } \\
\cline { 2 - 5 } Ingredients & $\mathbf{T}_{\mathbf{1}}$ & $\mathbf{T}_{\mathbf{2}}$ & $\mathbf{T}_{\mathbf{3}}$ & $\mathbf{T}_{\mathbf{4}}$ \\
\hline Processed cassava peel meal & 20.00 & 20.00 & 20.00 & 20.00 \\
Sorghum & 56.72 & 56.72 & 56.72 & 56.72 \\
GNC & 19.28 & 19.28 & 19.28 & 19.28 \\
Bone meal & 2.00 & 2.00 & 2.00 & 2.00 \\
Salt & 1.00 & 1.00 & 1.00 & 1.00 \\
Premix & 1.00 & 1.00 & 1.00 & 1.00 \\
Total (\%) & 100.00 & 100.00 & 100.00 & 100.00 \\
Calculated CP (\%) & 14.00 & 14.00 & 14.00 & 14.00 \\
\hline
\end{tabular}

$\mathrm{T}_{1}$ - Sun-dried cassava peel meal, $\mathrm{T}_{2}$ - Soaked cassava peel meal, $\mathrm{T}_{3}$ - Boiled cassava peel meal, $\mathrm{T}_{4}$ - Fermented cassava peel meal, GNC - Groundnut cake, CP - Crude protein

\section{Management of experimental animals and experimental design}

Twelve (12) growing red sokoto bucks with average body weight of $13 \pm 1 \mathrm{~kg}$ were randomly divided into four dietary groups of three animals per group in a completely randomized design (CRD). Group $1\left(\mathrm{~T}_{1}\right)$ was the control group with $20 \%$ sundried cassava peel meal in their diet, Group $2\left(\mathrm{~T}_{2}\right)$ received $20 \%$ soaked cassava peel meal, Group $3\left(\mathrm{~T}_{3}\right)$ had $20 \%$ boiled cassava peel meal in their diet and Group $4\left(\mathrm{~T}_{4}\right)$ received $20 \%$ fermented cassava peel meal. The bucks were confined in individual pens and had access to fresh drinking water ad libitum. Experimental animals were treated with antibiotic (oxytetracycline L.A) at $1 \mathrm{~mL} / 10 \mathrm{~kg}$ live weight and ivermectin injection at $1 \mathrm{~mL} / 50 \mathrm{~kg}$ live weight to control against ecto and endo-parasites prior to the commencement of the experiment. Feed intake was measured daily and bucks were weighed weekly with a hanging scale. The experiment lasted 70 days.

\section{Proximate analysis}

The standard method described by AOAC (2000) was used for the determination of dry matter, crude protein, crude fibre, ether extract and ash.

\section{Statistical analysis}

Data were subjected to analysis of variance (ANOVA) of SAS (2002) Linear Model and significant differences between means were separated using Fishers Least Significant Difference (LSD) at $5 \%$ level of probability.

\section{Results and discussion}

Table 2 shows the chemical composition of diets containing differently processed cassava peel meal and all the parameters observed were significantly $(\mathrm{p}<0.05)$ influenced by the processing methods of cassava peels. The observed DM value was significantly $(\mathrm{p}<0.05)$ higher in $\mathrm{T}_{3}(92.53$ \%) having boiled cassava peel meal. The $\mathrm{CP}$ and $C F$ had significantly $(p<0.05)$ higher values in $\mathrm{T}_{3}(9.48 \%$ and $13.59 \%$, respectively) containing boiled cassava peel meal. Values observed for EE were significantly $(\mathrm{p}<0.05)$ higher in $\mathrm{T}_{4}(7.43 \%)$ and lower in $\mathrm{T}_{1}(6.03 \%)$ while Ash was higher significantly $(\mathrm{p}<0.05)$ in the diet containing boiled cassava peel meal $\left(\mathrm{T}_{3}\right.$; $6.55 \%)$ but lower in the diet containing soaked cassava peel meal $\left(\mathrm{T}_{2} ; 4.81 \%\right)$. The proximate values obtained for cassava peels were similar to values reported by Kalio et al. (2014) for cassava peels except for ash 


\section{Effects of diets containing processed cassava peel meal}

content which was slightly lower. The dry matter content of the experimental diets $(90.57-92.53 \%)$ was higher than the range of $87.52-89.64 \%$ reported by Ukanwako and Ibeawuchi (2014). The crude protein contents of the diets containing differently processed cassava peel meal were within the 6-8 \% crude protein values recommended by NRC (1985). Diets containing boiled and fermented cassava peel meal $\left(\mathrm{T}_{3}\right.$ and $\mathrm{T}_{4}$, respectively) had CP values above the critical level of $7 \%$ for ruminants (Lanyasunya et al., 2006). The result of this study suggests that cassava peels, irrespective of the method of processing, will provide adequate nitrogen requirement for rumen micro-organisms to maximally digest the components of the dietary fiber leading to the production of volatile fatty acids (Okoruwa et al., 2016). Goats require adequate dietary ? bre for normal rumen function, as such, dietary ? bre contributes signi? cantly to the balancing of nutrient requirements and also plays a pivotal role through its in? uence in and interaction with the intake and digestion of nutrients $(\mathrm{Lu}$ et al., 2005). The dietary fibre content reported in the present study for diets containing differently processed cassava peel meal falls within values $(7.40-12.23$ \%) reported by Fajemisin et al. (2018) except for diet $\mathrm{T}_{3}$ which was slightly above the reported value.

Table 2: Proximate Composition (\%) of Experimental Diets

\begin{tabular}{lcccccc}
\hline & \multicolumn{7}{c}{ Treatments } & & \\
Parameters & $\mathbf{T}_{\mathbf{1}}$ & $\mathbf{T}_{\mathbf{2}}$ & $\mathbf{T}_{\mathbf{3}}$ & $\mathbf{T}_{\mathbf{4}}$ & $\mathbf{L S D}$ & $\mathbf{C P}$ \\
\hline Dry matter & $91.65^{\mathrm{b}}$ & $90.57^{\mathrm{c}}$ & $92.53^{\mathrm{a}}$ & $91.72^{\mathrm{b}}$ & 0.45 & 92.64 \\
Crude Protein & $6.92^{\mathrm{b}}$ & $6.74^{\mathrm{b}}$ & $9.48^{\mathrm{a}}$ & $8.02^{\mathrm{b}}$ & 1.19 & 6.45 \\
Crude Fiber & $11.63^{\mathrm{b}}$ & $10.68^{\mathrm{c}}$ & $13.59^{\mathrm{a}}$ & $12.12^{\mathrm{b}}$ & 0.55 & 14.01 \\
Ether Extract & $6.03^{\mathrm{d}}$ & $6.60^{\mathrm{c}}$ & $6.97^{\mathrm{b}}$ & $7.43^{\mathrm{a}}$ & 0.34 & 5.23 \\
Ash & $6.07^{\mathrm{b}}$ & $4.81^{\mathrm{d}}$ & $6.55^{\mathrm{a}}$ & $5.60^{\mathrm{c}}$ & 0.27 & 6.47 \\
\hline
\end{tabular}

$\mathrm{a}, \mathrm{b}, \mathrm{c}, \mathrm{d}$, means in the same row differs significantly $(\mathrm{p}<0.05), \mathrm{T}_{1}$ - Sun-dried cassava peel meal,

$\mathrm{T}_{2}$ - Soaked cassava peel meal, $\mathrm{T}_{3}$ - Boiled cassava peel meal, $\mathrm{T}_{4}$ - Fermented cassava peel meal, LSD - Least significant difference, CP - Cassava peel

The performance of growing red Sokoto bucks fed diets containing differently processed cassava peel meal is presented in Table 3. The result showed significant $(\mathrm{p}<0.05)$ differences in all the parameters evaluated with the exception of average daily weight gain, average daily feed intake, and feed to gain ratio. Bucks fed fermented cassava peel meal diet $\left(\mathrm{T}_{4}\right)$ had final weight $(19.63 \mathrm{~kg})$ greater than bucks fed diet $\mathrm{T}_{3}(18.47 \mathrm{~kg})$, but similar to bucks fed diets $T_{1}(19.03 \mathrm{~kg})$ and $T_{2}(18.77 \mathrm{~kg})$. Bucks on diet containing fermented cassava peel meal $\left(T_{4}\right)$ also had significantly $(\mathrm{p}<0.05)$ higher weight gain $(6.63 \mathrm{~kg})$ and equally consumed statistically more feed $(19.93 \mathrm{~kg})$ than bucks on diets containing soaked (5.76 kg and $19.11 \mathrm{~kg}$, respectively) and boiled $(5.47 \mathrm{~kg}$ and $18.14 \mathrm{~kg}$, respectively) cassava peel meals. The average daily weight gain of the bucks showed no significant $(\mathrm{p}>0.05)$ difference irrespective of the processing method employed, though bucks on diet $\mathrm{T}_{4}$ had numerically higher average daily weight gain. The average daily feed intake and feed to gain ratio were similar $(\mathrm{p}>0.05)$ across the treatments, although, bucks fed diet $\mathrm{T}_{4}$ (fermented cassava peel meal) had numerically higher average daily feed intake and the best feed to gain ratio. The significantly higher weight gain observed in bucks fed diet $T_{4}$ (fermented cassava peel meal) is evident from the fact that bucks on this treatment consumed more feed, probably due to higher reduction of anti- 
nutrients as a result of processing (i.e. fermentation) which enhanced better nutrient utilization in the diet (Akintunde et al., 2018). The weight gain and average daily weight gain of bucks fed the experimental diets were in agreement with reported values $(2.02-6.99 \mathrm{~kg}$ and $36.07-$ $124.82 \mathrm{~g} /$ day respectively) by Anya and Ozung (2018) in their study of the performance and carcass characteristics of WAD goats fed cassava peel meal based diets supplemented with African yambean concentrate. Average daily feed intake reported in the present study falls within the range $(215.30-290.25 \mathrm{~g} /$ day $)$ reported by Fasae et al. (2012). The feed to gain ratio showed that bucks fed diet containing fermented cassava peel meal $\left(\mathrm{T}_{4} ; 3.06\right)$ were more efficient in feed utilization over those on diets $\mathrm{T}_{3}$ (3.36) and $\mathrm{T}_{2}$ (3.34), although the difference was not significant. Generally, the performance of animals on diet containing fermented cassava peel meal was better in comparison with animals on other diets; which is in line with the report of Ari et al. (2017) who reported fermentation as the best processing method that will guarantee the preservation of essential nutrients. This explains why bucks on fermented cassava peel meal diets had better performance, in addition they were more efficient in the conversion of feed to flesh.

Table 3: Performance of growing red sokoto bucks fed diets containing processed cassava peel meal

\begin{tabular}{lccccc}
\hline & \multicolumn{5}{c}{ Treatments } \\
Parameters & $\mathbf{T}_{\mathbf{1}}$ & $\mathbf{T}_{\mathbf{2}}$ & $\mathbf{T}_{\mathbf{3}}$ & $\mathbf{T}_{\mathbf{4}}$ & $\mathbf{L S D}$ \\
\hline Initial weight $(\mathrm{kg})$ & 13.30 & 13.00 & 13.00 & 13.00 & 1.72 \\
Final weight $(\mathrm{kg})$ & $19.03^{\mathrm{ab}}$ & $18.77^{\mathrm{ab}}$ & $18.47^{\mathrm{b}}$ & $19.63^{\mathrm{a}}$ & 0.97 \\
Weight gain (kg) & $5.70^{\mathrm{b}}$ & $5.76^{\mathrm{b}}$ & $5.47^{\mathrm{b}}$ & $6.63^{\mathrm{a}}$ & 1.20 \\
Average daily weight gain (g/day) & 81.43 & 82.38 & 78.10 & 94.76 & 17.12 \\
Total feed intake (kg) & $18.37^{\mathrm{c}}$ & $19.11^{\mathrm{b}}$ & $18.14^{\mathrm{d}}$ & $19.93^{\mathrm{a}}$ & 1.21 \\
Average daily feed intake (g/day) & 262.49 & 273.03 & 259.13 & 284.74 & 74.50 \\
Feed/gain ratio & 3.22 & 3.34 & 3.36 & 3.06 & 1.20 \\
\hline
\end{tabular}

a, b, c, d, means in the same row differs significantly $(\mathrm{p}<0.05), \mathrm{T}_{1}$ - Sun-dried cassava peel meal,

$\mathrm{T}_{2}$ - Soaked cassava peel meal, $\mathrm{T}_{3}$ - Boiled cassava peel meal, $\mathrm{T}_{4}$ - Fermented cassava peel meal, LSD - Least significant difference

Table 4 shows the economics of feeding bucks with diets containing differently processed cassava peel meal. Cost per 100 $\mathrm{kg}$ diet and cost per kilogram of the experimental diets were significantly $(\mathrm{p}<0.05)$ higher in $\mathrm{T}_{3} \quad(\mathrm{~N} 7220.40$ and N72.20, respectively). Total feed consumed as well as total cost of feed were significantly higher $(\mathrm{p}<0.05)$ in $\mathrm{T}_{4}(19.93 \mathrm{~kg}$ and N1429.06, respectively); this is evident from the fact that animals in this treatment had higher feed intake. Feed cost per kilogram weight gain was lowest for bucks fed fermented cassava peel meal diet and this differed significantly $(\mathrm{p}<0.05)$ from the corresponding costs obtained for bucks fed sundried, soaked and boiled cassava peel meal diets. The result obtained in this study indicates that there might not be much difference in terms of profitability when differently processed cassava peel meal diets are fed to growing red Sokoto bucks. However, feeding fermented cassava peel meal will nonetheless result in maximum feed utilization through improved feed intake and weight gain. The cost of feed per kilogram of weight gain was lower $(\mathrm{N} 215.55)$ in diet $\mathrm{T}_{4}$ with fermented cassava peel meal because animals in the treatment had higher live weight gain which agreed with similar observations made by Maigandi et al. (2002). 


\section{Effects of diets containing processed cassava peel meal}

Table 4: Cost economics of diets containing processed cassava peel meal fed to growing red sokoto bucks

\begin{tabular}{lccccc}
\hline & \multicolumn{5}{c}{ Treatments } \\
Parameters & $\mathbf{T}_{\mathbf{1}}$ & $\mathbf{T}_{\mathbf{2}}$ & $\mathbf{T}_{\mathbf{3}}$ & $\mathbf{T}_{\mathbf{4}}$ & $\mathbf{L S D}$ \\
\hline Cost $/ 100 \mathrm{~kg}$ diet $(\mathrm{N})$ & $7023.07^{\mathrm{d}}$ & $7120.40^{\mathrm{c}}$ & $7220.40^{\mathrm{a}}$ & $7170.40^{\mathrm{b}}$ & 7.26 \\
Cost $/ \mathrm{kg}(\mathrm{N})$ & $70.23^{\mathrm{d}}$ & $71.20^{\mathrm{c}}$ & $72.20^{\mathrm{a}}$ & $71.70^{\mathrm{b}}$ & 0.07 \\
Total feed consumed $(\mathrm{kg})$ & $18.37^{\mathrm{c}}$ & $19.11^{\mathrm{b}}$ & $18.14^{\mathrm{d}}$ & $19.93^{\mathrm{a}}$ & 0.05 \\
Total cost of feed $(\mathrm{N})$ & $1290.14^{\mathrm{d}}$ & $1360.71^{\mathrm{b}}$ & $1309.78^{\mathrm{c}}$ & $1429.06^{\mathrm{a}}$ & 4.69 \\
Initial weight $(\mathrm{kg})$ & 13.33 & 13.00 & 13.00 & 13.00 & 1.72 \\
Final weight $(\mathrm{kg})$ & $19.03^{\mathrm{ab}}$ & $18.77^{\mathrm{ab}}$ & $18.47^{\mathrm{b}}$ & $19.63^{\mathrm{a}}$ & 0.97 \\
Weight gain $(\mathrm{kg})$ & $5.70^{\mathrm{b}}$ & $5.76^{\mathrm{b}}$ & $5.47^{\mathrm{b}}$ & $6.63^{\mathrm{a}}$ & 0.29 \\
Feed cost $/ \mathrm{kg}$ weight gain $(\mathrm{N})$ & $226.74^{\mathrm{b}}$ & $236.25^{\mathrm{ab}}$ & $239.45^{\mathrm{a}}$ & $215.55^{\mathrm{c}}$ & 11.00 \\
\hline $\mathrm{a}, \mathrm{b}, \mathrm{c}, \mathrm{d}$, means in the same row differs significantly $(\mathrm{p}<0.05), \mathrm{T}_{1}$ - Sun-dried cassava peel meal, \\
$\mathrm{T}_{2}$ - Soaked cassava peel meal, $\mathrm{T}_{3}$ - Boiled cassava peel meal, $\mathrm{T}_{4}$ - Fermented cassava peel meal, LSD - Least \\
significant difference
\end{tabular}

\section{Conclusion}

This study shows that inclusion of $20 \%$ fermented cassava peel meal in the diet of growing red Sokoto bucks resulted in better performance of the bucks through improved feed intake and weight gain with a subsequent reduction in the cost of feed per kilogram weight gain. It was therefore concluded that out of the three processing methods employed, fermentation was the best method.

\section{References}

Abdurrahman, S. L. and Kibon, A. U. 2017. Effects of substituting groundnut haulms with Poliostigma reticulatum hay on liveweight changes of red Sokoto bucks in semi-arid zone, Nigeria. Dutse Journal of Agriculture and Food Security, 4(1): 235-240

Ahamefule, F. O. and Udo, M. D. 2010. Performance of West African Dwarf (WAD) goats fed raw and processed pigeon pea (Cajanus cajan) seed meal based diets. Nigerian Journal of Animal Production, 32(2): 227-236

Ahmed, M. M., Abubakar, M. M., Lawan, M., Shu'aibu, I and Tijjani, A. M. 2015. Urinary and intestinal Schistosomiasis among primary school age children in
Dutse, Jigawa State, Nigeria. International Journal of Biological Sciences, 2(1): 15-22

Akintunde, A. R., Oguntoye, M. A., Adeoye, S. O. and Azuaga, C. I. 2018. Growth performance and nutrient digestibility of Japanese quail chicks (Coturnix coturnix japonica) fed diets containing raw and processed pigeon pea seed meal based diets with enzyme (Vegpro) supplementation. Nigerian Journal of Animal Science, 20(4):392-401

Akpodiete, O. J. and Inoni, O. E. 2000. Economics of production of broiler chickens fed maggot meals as replacement of fish meal. Nigerian Journal of Animal Production, 27: 59-63

Anaeto, M., Sawyerr A. F., Alli, T. R., Tayo, G. O., Adeyeye, J. A. and Olarinmoye, A. O. 2013. Cassava Leaf Silage and Cassava Peel as Dry Season Feed for West African Dwarf Sheep. Global Journal of Science Frontier Research Agriculture and Veterinary Sciences, 13(2): 1-4

Anya, M. I. and Ozung, P. O. 2018. Performance and carcass characteristics of West African Dwarf (WAD) goats fed cassava 
pee 1 meal based diets supplemented with African y a m bean concentrate. International Journal of Advances in Agricultural Science and Technology, 5(7): 95-108

AOAC 2000. Association of Official Analytical Chemists. "Official Method of Analysis" $4^{\text {th }}$ Edition (129-135), Washington D.C., U.S.A.

Ari, M. M., Ayanwale, B. A. and Adama, T. Z. 2017. Evaluation of different processing methods of soya beans (Glycine max) on its nutritive value and the performance of broilers: A qualitative selection approach for extension. International Journal of Livestock Production, 8(7): 113124

Ayanwale, B. A. 1999. Performance and carcass characteristic of broilers fed sodium sesquicarbonate processed soyabean diets. Tropical Journal of Animal Science, 2: 8593

Ayanwale, B. A. and Kolo, E. S. 2001. Effects of cooking and fermentation time on the nutritive value of soya beans for broilers. Nigerian Society for Experimental Biology, 1:3.

Fajemisin, A. N., Ibhaze, G. A., Oluwaloyo, O. E. and Omotoso, O. B. 2018. Dietary effect of Pleurotus pulmonaris treated cocoa bean shell meal on fibre fractions utilization by the West African Dwarf goats. Nigerian Journal of Animal Production, 45(5): 169-175

Fajemisin, A. N., Omotoso, O. B. and Ayelotan, T. A. 2015. Sepium and Acacia nilotica tomentosa. Proceedings of the $40^{\text {th }}$ Annual Conference of Nigerian Society for Animal Production. Pp 468-471
FAO 1991. Food and Agriculture Organization of the United Nations, Livestock and Livestock Products. Quarterly Bulletin of Statistics, FAO, Rome, Italy, 4(3): 39

Fasae, O. A., Idowu, O. M., Moronkola, A. I. and Ijaduola, O. A. 2012. Availability of cassava residues and by-products for goat production in cassava based farming system. Nigerian Journal of Animal Science, 39: 161-168

Kalio, G. A., Ayuk, A. A. and Agwunobi, L. N. 2014. Performance of West African Dwarf (WAD) goats fed $\mathrm{N}$-treated source and forage supplemented cassava peels in humid Cross River State, Nigeria. American Journal of Experimental Agriculture, 4(6): 629-638

Kum a r, S., Rama Rao, C.A., K a r e e m u l l a, K. a n d Venkateswarlu, B. 2010. Role of goats in livelihood security of rural poor in the less favoured environments. Indian Journal of Agricultural Economics, 65 (4): 760-781

Lanyasunya, T. P., Rong, W. H., Abdulrazak, S. A., Kaburu, P. K., Makori, J. O., Onyago, T. A. and Mwangi, D. M. 2006. Factors limiting use of poultry waste as protein supplement for dairy cattle on small holder farms in Kenya. International Journal of Poultry Science, 5: 75-80

Lu, C. D., Kawas, J. R. and Mahgoub, $O$. G. 2005. Fibre digestion and utilization in goats. Small Ruminant Research, 60: 45-52

Maigandi, S. A., Tukur, H. M. and Daneji, A. I. 2002. Fore-stomach digesta in the diet of growing sheep; performance and 
economics of production. Sokoto Journal of Veterinary Sciences, 4(2): 16-21

Martin, A. M. 2001. The future of the world food system. Outlook on Agriculture, 30(1): 11-19

Oboh, G. 2006. Nutrient enrichment of cassava peels using a mixed culture of Saccharomyces cerevisae and Lactobacillus spp. solid media fermentation. Electronic Journal of Biotechnology, 9(1): 46-49

Okoruwa, M. I., Bamigboye, F. O. and Agbadu, A. 2016. Rumen metabolites and thermophysiological response of West African Dwarf sheep as influenced by ficus foliage with differently processed breadfruit meals. Global Journal of Agricultural Research, 4(5): 28-38

Oyebanji, O. O., Adeyemi, S. B., Agboola, O. O. and Bolarinwa, K. 2017. Taxonomy, ethnobotany and vegetation analysis of biodiversity in Dutse Local Government, Jigawa State, Nigeria. FUW trends in Science and Technology Journal, 2(2): 679-683

Oppong-Apane, K. 2013. Different forms of cassava used for animal feed globally. In: Cassava as animal feed in Ghana: Past, Present and Future. B. Bedane, C. Ly and H.P.S. Makkar (Eds). Food and Agricultural Organization of the United Nations, Rome, Accra. Pp 26. Retrieved from http://www.fao.org/3/a-i3304e.pdf
Ozung, P. O., Nsa, E. E., Ebegbulem, V. N. and Ubua, J. A. 2011. The potentials of small ruminant production in Cross River rain forest zone of Nigeria: A Review. Continental Journal of Animal and Veterinary Research, 3(1): 33-37

Ozung, P. O. 2009. The effect of sun-dried cassava peel meal on performance, blood chemistry and reproductive potential of female rabbits. M.Sc. Thesis, Department of Animal Breeding and Physiology, College of Animal Science, University of Agriculture, Makurdi. Pp 155

Salami, R. I. and Odunsi, A. A. 2003. Evaluation of processed cassava peels meals as substitutes for maize in the diets of layers. International Journal of Poultry Science, 2(2): $112-116$.

SAS 2002. Statistical Analysis Institute. Users guide, Statistical Analysis Institute, Inc. Carry North, Caroline, USA

Ukanwoko, A. I. and Ibeawuchi, J. A. 2014. Evaluation of cassava peelcassava leaf meal based diets for milk production by the West African Dwarf Goats in South Eastern Nigeria. Journal of Agriculture and Veterinary Science, 7(5): 27-30.

Received: $20^{\text {th }}$ August, 2019 Accepted: $19^{\text {th }}$ December, 2019 